\title{
ANALISA PEMBANGUNAN PARTISIPATIF DALAM MUSRENBANG-DES TAHUN 2017 DI GAMPONG PANGGONG KECAMATAN JOHAN PAHLAWAN KABUPATEN ACEH BARAT
}

\author{
Fadhil Ilhamsyah ${ }^{1}$, Jumpa Parningotan Purba ${ }^{2}$ \\ Fakultas Ilmu Sosial dan Ilmu Politik, Universitas Teuku Umar \\ ${ }^{1}$ email: ilhamsyah355@gmail.com \\ 2email: jumpasidadolog@gmail.com
}

\begin{abstract}
This research aims to find out how the implementation of participatory development and to know the factors that affect public participation Gampong Panggong subdistrict of West Aceh Regency Hero Johan. Methods used in this research is descriptive qualitative method where data is taken from interviews, field notes, documents, memos and other documents to get the proper interpretation. The results showed that overall the participatory development implemetasi in Gampong Panggong subdistrict of Aceh Heroes Baratmasih Johan less good, in this case only a part of the community that are involved in the planning development. This is due to social and economic factors which the community at large as a fisherman so just focus on the fulfillment of survival. In addition the implementation of planning construction of Gampong Panggong subdistrict of West Aceh Regency Hero Johan. dietemukannya multiple factors that affect the level of public participation in the planning of development in Gampong Panggong is the factor endowments include presence awareness, public participation, and support from the Government and society. While restricting factors include poor quality of education, low income levels, limited employment and diperdesaan.
\end{abstract}

Keywords: Implemetasi, Participatory development 


\section{PENDAHULUAN}

Di dalam bernegara ataupun berbangsa yang menjadi persoalan dalam proses penyelenggaran pemerintah, baik dari tingkat atas sampai tingkat bawah adalah bagaimana atau menciptakan sistem pemerintahan yang dapat mengemban fungsinya yaitu, untuk mensejahterakan masyarakat secara merata ataupun adil. Untuk mewujudkan hal tersebut, maka Pemerintah harus melakukan pembangunan. Pembangunan yang dimaksud adalah pembangunan partisipatif selain melihat kinerja pemerintah, dapat juga membawa kemajuan bagi masyarakat sesuai dengan perkembangan tuntutan zaman.

Pembangunan partisipatif adalah suatu proses pembangunan yang memberdayakan masyarakat mulai dari tahap perencanaan, pelaksanaan hingga pengawasan pembangunan. Disamping itu diharapkan pula masyarakat dapat menempati prioritas sebagai penikmat hasil pembangunan. Namun untuk mencapai keadaaan itu kemandirian masyarakat tidaklah cukup melainkan diperlukan partisipasi aktif semua element yang ada termasuk kerjasama Pemerintah dengan stake holder yang ada.

Dimana pembangunan bertujuan untuk mewujudkan masyarakat yang adil, makmur, dan sejahtera. Tentu dalam tahap pembangunan yang paling diutamakan dalam ini adalah tahap perencanaan karena perencanaan merupakan suatu hal sebagai tolak ukur di dalam menilai hasil dari pembangunan di suatu negara maupun di suatu daerah. Sehingga dalam proses perencanaan pembangunan tentu pemerintah perlu melibatkan partisipatif masyarakat dalam melakukan pembangunan. Dengan kata lain, Partisipasi masyarakat merupakan sebuah kata kunci agar pembangunan bisa sukses (Arif, 2006: h. 149).

Tentu dalam proses perencanaan partisipatif maka perlu diadakan Musyawarah Pembangunan Desa (MUSRENBANGDES). Penyelenggaraan Musrembang wajib diselengggarakan menurut Undang-Undang Nomor 6 Tahun 2014 Tentang Desa. Sedangkan menurut Permendagri Nomor 66 Tahun 2007 Tentang Perencanaan Desa pasal 1 angka 11 yang berbunyi: "Musyawarah perencanaan pembangunan desa yang selanjutnya (Musrenbang-Desa) adalah forum musyawarah tahunan yang dilaksanakan secara partisipatif oleh para pemangku kepentinganDesa (pihak berkepentingan untuk mengatasi permasalahan Desa dan pihak yang terkena dampak hasil musyawarah) untuk meyepakati rencana kegiatan di Desa 5 (lima) dan 1 (satu) tahunan. Mengingat hal tersebut maka pemerintah Aceh Barat mengeluarkan Peraturan Bupati Aceh Barat Nomor 95 Tahun 2017 Tentang Pedoman Pelaksanaan Musyawarah Perencanaan Pembangunan Di Tingkat Gampong pasal 1 angka 8 yang berbunyi: “ Musyawarah Gampong adalah permusyawaratan dan pemufakatan dalam berbagai kegiatan adat, pemerintahan, pembangunan dan kemasyarakatan yang dipimpin oleh Tuha Peut Gampong dan dihadiri oleh Pemerintah Gampong, lembaga-lembaga adat, para pemimpin agama di tingkat Gampong dan masyarakat.

Merujuk pada hal tersebut maka setiap pemerintah desa harus melakukan adanya Musrenbangdes sebagai acuan dalam menyusun rencana kerja yang akan dilakukan. Demikian halnya Pemerintah Gampong panggong di dalam menyusun rencana kerja juga melakukan adanya Musrenbangdes sebagai salah satu aspek penting dalam penyelenggaraan pemerintahan yang baik sehingga dibukanya peluang bagi masyarakat untuk turut serta dalam keputusan pembangunan yang akan dilaksanakan.

Sementara dalam realitanya yang didapatkan penulis dalam observasi awal masyarakat Gampong panggong belum semua anggota masyarakatterlibat dalam proses perencanaan yang dimana masyarakat masih bersifat pasif. Sifat masyarakat dalam menghadiri Musrenbangdes yang masih di bawah rata-rata disebabkan dengan berbagai macam alasan yang terjadi.Hal ini di dasari karena kondisi sosial ekonomi masyarakat Gampong Panggong. Selain hal tersebut belum ada pemberitaan secara rinci dari pemerintah gampong mengenai proses perencanaan pembangunan. Artikel ini akan membahas lebih lanjut tentang penerapan pembangunan partisipatif di Gampong Panggong Kecamatan Johan Pahlawan Kabupaten Aceh Barat Tahun 
2017 dan Faktor-faktor apa saja yang menghambat tingkat pembangunan Partisipasif Masyarakatdi Gampong Panggong Kecamatan Johan Pahlawan Tahun 2017.

\section{Konsep Implemetasi}

Model pendekatan implementasi kebijakan yang dirumuskan Van Meter dan Van Horn dalam buku (Agustino, 2006: h.124) disebut dengan A Model of the Policy Implementation. Proses implementasi ini merupakan sebuah abstraksi atau performansi suatu perwujudan kebijakan yang pada dasarnya secara sengaja dilakukan untuk meraih kinerja implementasi kebijakan yang tinggi yang berlangsung dalam hubungan berbagai variabel. Model ini mengandaikan bahwa implementasi kebijakan berjalan secara linear dari keputusan politik, pelaksana dan kinerja kebijakan publik. Model ini menjelaskan bahwa kinerja kebijakan dipengaruhi oleh beberapa variabel yang saling berkaitan, variable-variabel tersebut yaitu:

1. Standar dan sasaran kebijakan / ukuran dan tujuan kebijakan

Kinerja implementasi kebijakan dapat diukur tingkat keberhasilannya dari ukuran dan tujuan kebijakan yang bersifat realistis dengan sosio-kultur yang ada di level pelaksana kebijakan. Ketika ukuran dan dan sasaran kebijakan terlalu ideal, maka akan sulit direalisasikan (Agustino, 2006: h.124). Van Meter dan Van Horn mengemukakan untuk mengukur kinerja implementasi kebijakan tentunya menegaskan standar dan sasaran tertentu yang harus dicapai oleh para pelaksana kebijakan, kinerja kebijakan pada dasarnya merupakan penilaian atas tingkat ketercapaian standar dan sasaran tersebut

2. Keberhasilan implementasi kebijakan sangat tergantung dari kemampuan memanfaatkan sumber daya yang tersedia. Manusia merupakan sumber daya yang terpenting dalam menentukan keberhasilan suatu implementasi kebijakan. Selain sumber daya manusia, sumber daya finansial dan waktu menjadi perhitungan penting dalam keberhasilan implementasi kebijakan.

3. Komunikasi dalam kerangka penyampaian informasi kepada para pelaksana kebijakan tentang apa menjadi standar dan tujuan harus konsisten dan seragamdari berbagai sumber informasi.Jika tidak ada kejelasan dan konsistensi serta keseragaman terhadap suatu standar dan tujuan kebijakan, maka yang menjadi standar dan tujuan kebijakan sulit untuk bisa dicapai.

4. Menurut pendapat Van Metter dan Van Horn dalam (Agustino, 2006: h.128): "sikap penerimaan atau penolakan dari agen pelaksana kebijakan sangat mempengaruhi keberhasilan atau kegagalan implementasi kebijakan publik. Hal ini sangat mungkin terjadi karena kebijakan yang dilaksanakan bukanlah hasil formulasi warga setempat yang mengenal betul permasalahan dan persoalan yang mereka rasakan.

5. Hal terakhir yang perlu diperhatikan guna menilai kinerja implementasi kebijakan adalah sejauh mana lingkungan eksternal turut mendorong keberhasilan kebijakan publik. Lingkungan sosial, ekonomi dan politik yang tidak kondusif dapat menjadi sumber masalah dari kegagalan kinerja implementasi kebijakan.

\section{Pembangunan Partisipatif}

Dalam hal pembangunan secara sederhana sering diartikan sebagai upaya untuk melakukan perubahan menjadi lebih baik. Perubahan yang dimaksud adalah perubahan menuju arah peningkatan dari keadaan semula, serta tidak jarang pula ada mengasumsikan bahwa pembangunan adalah pertumbuhan. Tahapan perencanaan pembangunan menurut ( Solihin, 2006: h.49)

1. Perumusan dan penentuan tujuan

2. Pengujian atau analisis opsi atau pilihan yang tersedia

3. Pemilihan rangkain tindakan atau kegiatan untuk mencapai tujuan yang telah ditentukan dan telah disepakati bersama. Dari ketiga tahapan perencanaan tersebut dapat di 
definisikan perencanaan pembangunan wilayah dan daerah sebagai berikut: suatu usaha yang sistematis dari berbagai pelaku (aktor) baik umum ( publik) atau pemerintah, swasta maupun kelompok masyarakat stakholder lainnya pada tingkatan yang berbeda untuk menghadapi saling ketergantungan dan keterkaitan aspek fisik, ekonomi, dan aspek lingkungan lainnya.

Faktor-Faktor Yang Mempengaruhi Tingkat Partisipasi Masyarakat Dalam pembangunan Adapun faktor pendorong partisipasi masyarakat dalam pembangunan menurut (Sastropoetra, $1988:$ h.23) yaitu:

a. Faktor Kesadaran Kemauan

Keikutsertaan dalam suatu kegiatan pembangunan bukan timbul begitu saja akan tetapi karena adanya yang mendorongnya untuk partisipasi. Salah satu diantaranya adalah faktor kesadaran masyarakat itu sendiri.

b. Adanya Partisipasi Masyarakat

Partisipasi yang didorong oleh solidaritas yang tinggi diantara sesama anggota masyarakat, apalagi yang memulai adalah pemimpin mereka. Sehingga keikutsertaan mereka bukan karena dorongan hati nurani sendiri, tetapi merupakan perwujudan kebersamaan saja, yang sudah merupakan kondisi sosial budaya masyarakat khususnya masyarakat pedesaan.

c. Adanya Dukungan Pemerintah Daerah dan Masyarakat

Pemerintah selaku pengembang amanat rakyat untuk membangun memanglah harus berperan, terutama pemerintah daerah. dalam hal ini pemerintah camat, mereka diharapkan mampu mendorongan masyarakat untuk berpartisipasi dalam pembangunan Desa. Mendatangi masyarakat untuk menghimbau dan usaha lainnya. Adanya dukungan dari masyarakat, baik dari tokoh masyarakat maupun warga secara umum. Partisipasi tokoh masyarakat turut membantu dalam mengawasi dan memberikan arahan kepada masyarakat yang kurang memahami tentang pembangunan Desa serta berperan sebagai kontrol sosial ditengah masyarakat.

Adapun faktor penghambat partisipasi masyarakat dalam pembangunan menurut (Sastropoetro, 1988: h.23) yaitu:

a. Rendahnya Kualitas Pendidikan

Sarana pendidikan masyarakat di Desa cenderung rendah. Masyarakat di Desa umumnya hanya berpendidikan SD, SMP dan SMA. Hal ini disebabkan karena masyarakat belum mengetahui seberapa besar pentingnya pendidikan untuk dirinya. Apabilah setelah menyelesaikan pendidikan hingga SMA atau lebih buruk hanya sampai SD saja orang tua akan menikahkan anak-anaknya sehingga masa depan pendidikan generasi penurus bangsa menjadi terputus. Dan hal ini menyebabkan mereka hanya bergelut pada lingkar kemiskinan karena minimnya pendidikan, rendahnya pendidikan ini juga menjadi akar permasalahan bahwa kurangnya inisiatif masyarakat dalam menghadapi masalahmasalah dalam kehidupan mereka.

b. Tingkat Pendapatan Yang Rendah

Produktivitas yang sangat rendah mengakibatkan rendahnya pendapatan riil. Pendapatan yang rendah mengakibatkan rendahnya simpanan, dan rendahnya investasi, dan rendahnya pembentukan modal. Pendapatan yang rendah mengakibatkan tabungan rendah pula. Tabungan yang rendah akan melemahkan pembentukan modal yang akhirnya kekurangan modal, masyarakat terbelakang, kekayaan alam belum dapat diolah, dan seterusnya sehingga merupakan lingkungan yang tidak berujung pangkal. Pada umunya masyarakat hanya bergantung pada alam.

c. Terbatasnya Lapangan Pekerjaan di Pedesaan 
Indonesia sebagai negara agraris sampai saat ini dapat dilihat dari besarnya jumlah penduduk yang masih mengandalkan penghasilanya serta menggantungkan harapan hidupnya pada sektor pertanian. Dominasi sektor pertanian sebagai mata pencariaan penduduk dapat terlihat nyata di daerah pedesaan. Sampai saat ini lapangan kerja yang tersedia di daerah pedesaan masih didominasi oleh sektor pertanian usaha bidang pertanian. Kegiatan usaha ekonomi produktif di daerah pedesaan masih sangat terbatas ragam dan jumlahnya, yang cenderung terpaku pada bidang pertanian (agribisnis). Bahkan berarti lapangan kerja di luar sektor pertanian tidak ada, akan tetapi masih sangat terbatas peluang.

\section{METODE PENELITIAN}

Metode yang digunakan dalam penelitian ini adalah metode deskriptif kualitatif. Data yang digunakan dalam penelitian ini yaitu data primer dan sekunder. Data primer yaitu diperoleh secara langsung dari penelitian melalui wawancara dengan informan yang berkaitan dengan masalah penelitian, data sekunder yaitu data yang diperoleh baik dalam bentuk angka maupun uraian.

\section{HASIL DAN PEMBAHASAN \\ Penerapan Pembangunan Pembangunan Partisipatif di Gampong Panggong Kecamatan Johan Pahlawan Kabupaten Aceh Barat}

Proses implementasi merupakan suatu perwujudan yang pada dasarnya secara sengaja dilakukan untuk meraih kinerja implementasi. Menurut Van Meter Van Horn menjelaskan bahwa kinerja kebijakan dipengaruhi oleh beberapa bagian yang saling berkaitan yaitu standard an sasaran kebijakan, sumber daya, sikap para pelaksana, komunikasi antar organisasi dan aktivitas para pelaksana, dan lingkungan sosial, ekonomi, dan politik. Pada tahap perencanaan pembangunan yang dilakukan kebijakan yang diterapkan adalah adanya pelaksanaan musyawarah perencanaan pembangunan. Gampong Panggong Kecamatan Johan Pahlawan Kabupaten Aceh Barat pada proses implementasi pembangunan partisipatif sudah dilakukan sesuai dengan kebijakan peraturan Bupati Nomor 95 Tahun 2017 Tentang Pedoman Pelaksanaan Musyawarah Perencanaan Pembangunan Di Tingkat Gampong.

Berdasarkan hasil penelitian dari informan terkhususnya aparatur pemerintah Gampong Panggong Kecamatan Johan Pahlawan Kabupaten Aceh Barat bahwa dalam pelaksanaan perecanaan pembangunan partisipatif di Gampong Panggong Kecamatan Johan Pahlawan Kabupaten Aceh Barat sebagai berikut:

Pemerintah Gampong Panggong Kecamatan Johan Pahlawan Kabupaten Aceh Barat, di dalam pelaksanaan perencanaan pembangunan partisipatif adanya melakukan musyawarah perencanaan pembangunan adanya pelibatan masyarakat, tetapi di dalam ada beberapa hal penghambat dalam pelaksanaan pembangunan seperti kondisi lingkungan sosial, ekonomi dan politik, dan rendahnya kualitas pendidikan masyarakat Gampong Panggong.

\section{Standar Dan Sasaran Kebijakan}

Standar dan sasaran kebijakan merupakan tolak ukur dari pada pelaksanaan kebijakan yang ingin dicapai oleh para pelaksana kebijakan. Hasil daripada kebijakan pada dasarnya merupakan penilaian atas tingkat ketercapaian standar dan sasaran tersebut. Implementasi kebijakan yang berhasil, bisa jadi gagal ketika para pelaksana, tidak sepenuhnya menyadari terhadap standar dan tujuan kebijakan.

\section{Pedoman Perencanaan Pembangunan}


Pemerintah Gampong Panggong Kecamatan Johan Pahlawan Kabupaten Aceh Barat dalam melaksanakan proses perencanaan pembangunan, adanya sebuah pedoman yang digunakan. Pedoman yang digunakan berlandaskan Peraturan Bupati Nomor 95 Tahun 2017 Tentang Pedoman Pelaksanaan Musyawarah Perencanaan Pembangunan Di Tingkat Gampong. Selain peraturan tersebut ditambah lagi dengan adanya PERMENDAGRI Nomor 114 Tahun 2014 Tentang Pedoman Pembangunan Desa. Namun pedoman ini masih disesuaikan oleh aparatur Gampong Panggong sesuai dengan kondisi Gampong Panggong. Sehingga dengan adanya standar maka setiap pembangunan yang dilakukan gampong akan menjadi tepat sasaran dan tujuan dari perencanaan pembangunan tersebut akan dapat dicapai.

\section{Sasaran Perecanaan Pembangunan}

Gampong Panggong Kecamatan Johan Pahlawan Kabupaten Aceh Barat, sasaran perencanaan pembangunan yang ingin dicapai adalah pembangunan yang dilaksanakan dapat terarah, tepat dan masyarakat gampong dapat menikmati hasi daripada pembangunan tersebut dan secara tidak langsung akan mendorong perekonomian masyarakat Gampong Panggong.

\section{Sumber Daya}

Keberhasilan suatu pelaksanaan kebijakan akan sangat tergantung dari kemampuan memanfaatkan sumber daya yang tersedia. Dimana di dalam setiap pelaksanaan dibutuhkan sumber daya yang berkualitas sesuai dengan keahlian masing-masing pelaksana kebijakan.

\section{Sumber Daya Manusia}

Sumber daya yang paling utama dalam pelaksanaan perencanaan pembangunan adalah sumber daya manusia.Kegagalan pembangunan disebabkan oleh manusianya yang tidak memiliki kompeten dibidangnya. Seperti tabel di bawah berikut:

Tabel 1

\section{Jumlah Penduduk Berdasarkan Tingkat Pendidikan}

\begin{tabular}{|c|c|c|c|}
\hline \multirow{2}{*}{ Jenis pendidikan } & \multicolumn{2}{|c|}{ Jenis kelamin } & \multirow{2}{*}{ Jumlah Jiwa } \\
\cline { 2 - 3 } & Laki-Laki & Perempuan & 32 \\
\hline Tidak Tamat SD & 20 & 12 & 372 \\
\hline SD & 230 & 142 & 359 \\
\hline SLTP & 199 & 160 & 272 \\
\hline SMU/SLTA & 121 & 151 & 18 \\
\hline Perguran Tinggi & 9 & 9 & 1053 \\
\hline Jumlah Total & 579 & 474 & \\
\hline
\end{tabular}

Sumber: Profil Gampong Panggong

Berdasarkan hal tersebut, maka sumber daya manusia berada di Gampong Panggong Kecamatan Johan Pahlawan Kabupaten Aceh Barat masih tergolong rendah karena masih banyak masyarakat yang tingkat pendidikannnya tamatan SD/Sederajat sebanyak 372 jiwa dan, tamatan SLTP/Sederajat sebanyak 395 jiwa. Sehingga bisa dikatakan bahwa SDM di Gampong Panggong Panggong tergolong rendah.

\section{Sumber Daya Finansial}

Sumber daya finansial di Gampong Panggong sudah memadai karena semua hasil musyawarah pembangunan yang akan dilakukan akan menjadi APBG. Hal ini dibuktikan dengan APBG Panggong. Seperti hal sebagai berikut:

Tabel 2

APBG Panggong Tahun 2017 


\begin{tabular}{|c|l|c|}
\hline No & \multicolumn{1}{|c|}{ Uraian } & Anggaran (Rp) \\
\hline 1 & Pendapatan & $989.406 .700,00$ \\
\hline 2 & PAG & $42.300 .000,00$ \\
\hline 3 & Alokasi Dana Desa & $751.505 .000,00$ \\
\hline 4 & Alokasi Dana Gampong & $195.600 .900,00$ \\
\hline 5 & Belanja & $961.659 .250,00$ \\
\hline 6 & Surplus/Defisit & $27.747 .450,00$ \\
\hline 7 & Pembiayaan & $42.300 .000,00$ \\
\hline 8 & Pembiayaan Netto & $42.000 .000,00$ \\
\hline 9 & Silpa & $14.552 .550,00$ \\
\hline
\end{tabular}

Sumber: APBG Panggong Tahun 2017

Berdasarkan hal diatas maka dapat disimpulkan dana Gampong Panggong sudah memadai untuk melaksanakan berbagai pembangunan.

\section{Komunikasi Antar Organisasi Dan Aktivitas Para Pelaksana}

Komunikasi sangat menentukan pencapaian dari pelaksanaan pembangunan partisipatif di Gampong Panggong Kecamatan Johan Pahlawan Kabupaten Aceh Barat. Pelaksanaan yang efektif terjadi apabila para pembuat keputusan sudah mengetahui apa yang mereka kerjakan. Pengetahuan yang akan mereka kerjakan dapat berjalan dengan baik bila komunikasi berjalan dengan baik.Sehingga setiap pelaksanaan pengawasan pembangunan harus dikomunikasikan dengan baik, baik dari aparatur pemerintah gampong kepada masyarakat maupun masyarakat kepada aparatur gampong.

\section{a. Alur Komunikasi Yang Dibangun}

Gampong Panggong Kecamatan Johan Pahlawan Kabupaten Aceh Barat jalur komunikasi yang dibangun adanya komunikasi timbal balik. Dimana setiap musyawarah perencanaan pembangunan yang akan dilaksanakan adanya upaya aparatur gampong untuk mengajak masyarakat untuk berpartisipasi dalam berbagai kegiatan gampong. selain hal tersebut aparatur gampong terlebih dahulu membuat pengumuman di masjid dan adanya usaha aparatur gampong untuk mengajak melalui surat undangan yang diberikan.

\section{b. Sikap Para Pelaksana}

Sikap penerimaan atau penolakan dari pelaksana kebijakan sangat mempengaruhi keberhasilan atau kegagalan pelaksanaan kebijakan. Sikap mereka akan dipengaruhi oleh pandangannya terhadap suatu kebijakan dan cara melihat pengaruh kebijakan itu terhadap kepentingan-kepentingan organisasinya dan kepentingan-kepentingan pribadinya.

\section{c. Keberlanjutan Aspirasi Masyarakat}

Pemerintahan Gampong Panggong Kecamatan Johan Pahlawan Kabupaten Aceh Barat, jika melihat ke belakang, bahwa pola perencanaan yang ada selalu menerima semua aspirasi masyarakat untuk perencanaan pembangunan. Tetapi aspirasi tersebut terkadang keberlanjutannya tidak ada dan penyebab aspirasi tersebut tidak ada lanjutan warga tidak mengetahui, menurut penilaian wargapembangunanyang dilakukan hanya mengulang yang sudah ada sehingga tidak ada kemajuan dan pembangunan yang dilakukan tidak merata sehingga seolaholah terlihat adanya kepentingan

\section{Lingkungan Sosial, Ekonomi, dan Politik}

Lingkungan eksternal dalam hal ini lingkungan ekonomi, sosial, dan politik turut mendorong keberhasilan kebiajak public.Lingkungan sosial, politik yang tidak kondusif dapat menjadi sumber masalah kegagalan kinerja pelaksanaan kebijakan.

\section{a. Lingkungan Sosial Politik}

Gampong Panggong Kecamatan Johan Pahlawan Kabupaten Aceh Barat, kondisi sosial politik disini adanya kelompok-kelompok di dalam masyarakat akibat daripada pemilihan Bupati 
tahun belakangan ditambah lagi kepercayaan masyarakat yang kurang terhadap setiap aparatur pemerintah gampong dan masyarakat mudah untuk terprovokasi oleh suatu issu.

\section{b. Kondisi Ekonomi}

Kondisi perekonomian masyarakat gampong Panggong Kecamatan Johan Pahlawan Kabupaten Aceh Barat, mayoritas penduduknya masih banyak tergantung terhadap penghasilan sebagai nelayan sehingga warga masih banyak hidup tergolong penduduk miskin.Masyarakat lebih tertarik kepada masalah-masalah pemenuhan kebutuhan sehari-hari seperti pemenuhan kelangsungan hidup. Berakibat masyarakat sangat susah dalam membagi waktu untuk ikut berpartisipasi. Seperti tabel dibawah:

Tabel 3

Jumlah Penduduk Gampong Panggong Berdasarkan KK Kemiskinan

\begin{tabular}{|c|c|c|}
\hline No & Dusun & Jumlah KK Miskin \\
\hline 1 & Selada & 55 \\
\hline 2 & Tomat & 51 \\
\hline 3 & Bayam & 47 \\
\hline 4 & Kangkung & 51 \\
\hline \multicolumn{2}{|c|}{ Total } \\
\hline
\end{tabular}

Sumber: Profil Gampong Tahun 2015

Berdasarkan tabel diatas maka dapat disimpulkan bahwa dari 343 jumlah Kepala Keluarga (KK) yang berada di Gampong Panggong Kecamatan Johan Pahlawan Kabupaten Aceh Barat, jumlah KK yang tergolong miskin 204 KK.Maka jumlah kepala keluarga penduduk yang tergolong miskin sebanyak 60\% dari keseluruhan jumlah KK yang berada di Gampong Panggong.

Faktor-Faktor Yang Mempengaruhi Tingkat Partisipasi Masyarakat Dalam Pembangunan

Di dalam menumbuhkan semangat untuk melakukan partisipasi peran serta masyarakat dalam kegiatan.Dibutuhkan dukungan yang kuat dari masyarakat dan aparatur pemerintah.

\section{Faktor Pendukung}

Adanya faktor pendorong partisipasi masyarakat dalam pembangunan sebagai berikut:

\section{a. Faktor Kesadaran Kemauan}

Faktor kesadaran masyarakat berpengaruh terhadap tingkat partisipasi. Peran dan kesadaran masyarakat perlu ditingkatkan partisipasi masyarakat dalam pembangunan akan dirasakan kewajiban bersama. Hal ini terjadi di Gampong Panggong Kecamatan Johan Pahlawan Kabupaten Aceh Barat, sebagian warga masih memiliki kesadaran namun masih banyak yang memiliki kesibukan untuk menyambung hidup.Hal ini terjadi karena adanya perbedaan tingkat kesadaran dan tingkat ekonomi masyarakat.

\section{b. Adanya Partisipasi Masyarakat}

Kelahiran Undang-Undang Nomor 23 Tahun 2014 Tentang Pemerintah Daerah memberikan kesempatan kepada masyarakat desa untuk mengatur dan mengurus rumah tangganya sendiri.Dengan Undang-Undang tersebut maka partisipasi masyarakat gampong Panggong Kecamatan Johan Pahlawan Kabupaten Aceh Barat, sangat diperlukan sehingga setiap aspirasi pembangunan bisa disampaikan.

\section{c. Adanya Dukungan Pemerintah Daerah dan Masyarakat}

Pembangunan partisispatif itu tidak hanya merupakan usaha daripada aparatur pemerintah gampong ataupun masyarakat saja.Tetapi hal ini merupakan suatu kegiatan bersama yang mana hasilnya dapat memberikan suatu kesejahteraan bagi penduduk gampong.sehingga dengan adanyapartisipasi setiap masyarakat dan dukungan aparatur gampong akan membuat setiap proses perencanaan pembangunan itu akan berhasil.

\section{Faktor Penghambat}


Adanya faktor penghambat partisipasi masyarakat dalam pembangunan sebagai berikut:

a. Rendahnya Kualitas Pendidikan

Masalah pendidikan di Gampong Panggong Kecamatan Johan Pahlawan Kabupaten Aceh Barat, masih tergolong rendah dimana masih banyaknya anaka-anak yang putus sekolah.Tingkat pendidikan yang tergolong rendah menyebabkan pemahaman masyarakat tentang pembangunan partisipatif masih kurang.

\section{b. Tingkat Pendapatan Yang Rendah}

Bahwa partisipasi masyarakat gampong Panggong Kecamatan Johan Pahlawan Kabupaten Aceh Barat, kurang baik disebabkan masyarakat kecenderungan apatis melibatkan diri, masyarakat lebih tertarik kepada masalah-masalah pemenuhan kebutuhan sehari-hari seperti pemenuhan makan.Seperti yang terjadi pada masyarakat Gampong Panggong mayoritas masyarakat bergantung pada hasil daripada melaut. Selain hal tersebut masyarakat merasa pesimis dengan pembangunan partisipatif dan menganggap bahwa hal tersebut tidak akan memberikan dampak positif bagi pembangunan gampong.

\section{c. Terbatasnya Lapangan Pekerjaan Di Pedesaan}

Pendidikan yang rendah menyebabkan pendapatan yang rendah sehingga usaha untuk mengembangkan ekonomi produktif tidak ada.Seperti yang terjadi di Gampong Panggong Kecamatan Johan Pahlawan Kabupaten Aceh Barat, dimana kegiatan usaha ekonomi produktif di gampong Panggong masih terbatas ragam dan jumlahnya.Sehingga masyarakt Gampong Panggong yang kebetulan berada di daerah pesisir di dalam menyambung hidup hanya bekerja sebagai nelayan.

\section{SIMPULAN}

Dari apa yang telah penulis kemukakan tersebut, dapat disimpulkan bahwa maka dapat disimpulkan sebagai berikut:

1. Penerapan pembangunan partisipatif di Gampong Panggong Kecamatan Johan Pahlawan Kabupaten Aceh Barat dapat dikategorikan kurang baik. Hal ini karena belum sesuainya dengan kebijana Peraturan Bupati Nomor 95 Tahun 2017 Tentang Pedoman Pelaksanaan Musyawarah Perencanan Pembangunan Di Tingkat Gampong. demikian pula tujuan pedoman dengan proses pelaksanaan pedoman musyawarah kurang melibatkan masyarakat dalam pembangunan partisipatif, hal ini dipengaruhi oleh faktor lingkungan sosial, dan ekonomi masyarakat. Selain itu, tidak adanya kesesuaian rencana kerja pembanguna gampong sesuai harapan masyarakat setempat.

2. Faktor-faktor yang menghambat impelementasi perencanaan Gampong Panggong tingkat partisipasi masyarakat dalam pembangunan salah satunya adalah rendahnya kualitas pendidikan sehingga pengetahuan masyarakat pembangunan partisipatif masih kurang. Selain hal tersebut masyarakat sudah pesimis disebabkan keputusan-keputusan pelaksanaan pembangunan tetap dari aparatur pemerintah gampong karena keberlanjutan aspirasi dari masyarakat tidak ada.

\section{REFERENSI}

Agustino, Leo. 2006. Dasar - Dasar Kebijakan Publik. Bandung: Cv Alfabeta.

Arif, syaiful. 2006.Reformasi Birokrasi dan Demokratisasi Kebijakan,.Malang: Avarroes Pres. 
Sastropoetro, Santoso R.A. 1988. Partisipasi, Komunilasi, Persuasi, dan Disiplin Dalam Pembangunan Nasional. Bandung : Alumni.

Wahab, Solihin, A. 2008. Analisis Kebijakan Dari Formasi Ke Implementasi Kebijakan Negara. Malang: Bumi Aksara.

Wrihatnolo, Randy R, dan Nugroho, Riant. 2006. Menejemen Pembangunan Indonesia Sebuah Pengantar dan Panduan. Jakarta: Elekx Media Komputindo.

Undang-Undang Nomor 6 Tahun 2014 Tentang Desa

Peraturan Bupati Aceh Barat Nomor 95 tahun 2017 Tentang Pedoman Pelaksanaan Musyawarah Perencanaan Pembangunan Di Tingkat Gampong. 